\title{
In vitro blood cell responsiveness to IFN-a predicts clinical response independently of IL28B in hepatitis $C$ virus genotype 1 infected patients
}

Nollaig M Bourke ${ }^{1}$, Mary-Teresa O'Neill ${ }^{1,2}$, Shahzad Sarwar ${ }^{3}$, Suzanne Norris ${ }^{4,5}$, Stephen Stewart ${ }^{2}$, John E Hegarty ${ }^{3}$, Nigel J Stevenson ${ }^{1}$ and Cliona O'Farrelly ${ }^{1,5^{*}}$

\begin{abstract}
Background: Treatment with interferon-alpha (IFN-a) and ribavirin successfully clears hepatitis C virus (HCV) infection in $50 \%$ of patients infected with genotype 1. Addition of NS3-4A protease inhibitors (PIs) increases response rates but results in additional side effects and significant economic costs. Here, we hypothesised that in vitro responsiveness of peripheral blood mononuclear cells (PBMCs) to IFN-a stimulation would identify patients who achieved sustained virological response (SVR) on dual therapy alone and thus not require addition of PIs.

Methods: PBMCs were isolated from HCV infected patients $(n=42)$, infected with either HCV genotype 1 or genotype 3, before commencing therapy and stimulated in vitro with IFN-a. Expression of the IFN stimulated genes (ISGs) PKR, OAS and MXA was measured and correlated with subsequent treatment response and IL28B genotype.

Results: Genotype 1 infected patients who achieved SVR had significantly higher pre-treatment expression of PKR $(p=0.0148)$, OAS $(p=0.0019)$ and MXA $(p=0.0019)$ in IFN-a stimulated PBMCs, compared to genotype 1 infected patients who did not achieve SVR or patients infected with genotype 3, whose in vitro ISG expression did not correlate with clinical responsiveness. IL28B genotype (rs 12979860) did not correlate with endogenous or IFN-a stimulated ISG responsiveness.

Conclusions: In vitro responsiveness of PBMCs to IFN-a from genotype 1 infected patients predicts clinical responsiveness to dual therapy, independently of IL28B genotype. These results indicate that this sub-group of HCV infected patients could be identified pre-treatment and successfully treated without PIs, thus reducing adverse side effects and emergence of PI resistant virus while making significant economic savings.
\end{abstract}

Keywords: Interferon stimulated genes, Protease inhibitors, Host predictive markers, IL28B genotype

\section{Background}

The standard of care for patients infected with hepatitis $\mathrm{C}$ virus (HCV) for the past decade has consisted of dual therapy with the anti-viral cytokine, interferon-alpha (IFN- $\alpha$ ) and the nucleoside analogue, ribavirin. IFN- $\alpha$ induces anti-viral immunity by upregulating hundreds of IFN stimulated genes (ISGs) [1], including many with potent direct and indirect anti-viral activity [2]. Response rates to therapy are highly variable, with patients infected

\footnotetext{
* Correspondence: cliona.ofarrelly@tcd.ie

'School of Biochemistry and Immunology, Trinity Biomedical Sciences Institute, Trinity College Dublin, Dublin 2, Ireland

${ }^{5}$ School of Medicine, Trinity College, Dublin 2, Ireland

Full list of author information is available at the end of the article
}

with genotype 1 (G1) having sustained virological response (SVR) rates of less than $50 \%$, whereas genotype 3 (G3) infected patients can achieve SVRs of up to $82 \%$ [3].

Increased insight into the viral life cycle of HCV has led to development of several new directly acting anti-viral agents (DAAs), including NS3-4A protease inhibitors (PIs). Several PIs, including telaprevir and boceprevir, are administered in combination with standard IFN- $\alpha$ /ribavirin treatment. Triple therapy increases response rates from less than $50 \%$ to $75 \%$ in some G1 infected cohorts $[4,5]$. However, PIs are expensive and associated with significant additional side effects, such as anaemia and rash, and emergence of drug resistant variants, a major challenge in cases of non-compliance with therapy. Identification of 
patients with a high probability of obtaining an SVR to dual therapy would obviate the need for additional PIs and alleviate these issues.

Multiple efforts have been made to accurately predict response to therapy using viral and host characteristics. Viral predictive markers include viral load and genotype, while host predictive markers include age, sex, race, and liver fibrosis stage [6]. Elevated serum levels of the chemokine CXCL10 have also been reported to be associated with non-response to IFN- $\alpha$ therapy [7]. Additionally, a single nucleotide polymorphism (SNP), rs12979860, in the recently described IFN $\lambda 4$ gene [8] is highly predictive of response $[9,10]$. The major $C$ allele correlates strongly with viral clearance particularly in patients infected with HCV G1. Nevertheless, no single marker or combination of markers accurately predicts patient response in individual cases.

We hypothesised that in vitro responsiveness to IFN- $\alpha$ would predict clinical responsiveness to dual therapy. Hepatic ISG expression is elevated pre-treatment in patients who fail to achieve SVR [11] and has been shown to be a stronger predictor of response than IL28B genotype [12]. However, liver biopsy is an invasive procedure with associated risks and has limited value as a prognostic tool. Leukocytes are sensitive responders to IFN- $\alpha$ and provide a more accessible alternative, requiring just a peripheral blood sample. In fact, in vivo upregulation of ISGs in PBMCs following therapeutic IFN- $\alpha$ is similar to ISG upregulation in vitro following IFN- $\alpha$ stimulation [13], suggesting in vitro PBMC responsiveness may indeed be an accurate reflection of in vivo clinical response.

IFN- $\alpha$ activates the JAK-STAT signalling pathway, leading to upregulation of over 500 ISGs [14]. PKR, OAS and MxA are three well-characterised ISGs, strongly induced by IFN- $\alpha$ in PBMCs, which have direct anti-viral action. Activation of PKR by virus results in inhibition of protein translation, including inhibition of viral mRNA translation through phosphorylation of the alpha subunit of eukaryotic protein synthesis initiation factor 2 (eIF2 $\alpha$ ) [15]. Indeed, $\mathrm{HCV}$ has evolved several mechanisms to block the action of this important regulator of translation $[16,17]$. OAS is an IFN regulated activator of latent ribonuclease RNase L, which is triggered by activated OAS to directly cleave RNA, including HCV RNA, thus destroying viral RNA products and producing pathogen associated molecular patterns (PAMPs) that further stimulate innate immune activity $[18,19]$. MxA recognises viral nucleocapsids and renders them redundant by wrapping around the viral structure and forming MxA/nucleocapsid oligomers [20]. MxA may also direct nucleocapsids to alternative sites in the cytoplasm, where they are not functional for RNA synthesis and likely to be immobilised and subsequently degraded [2]. Interestingly, we have demonstrated that the core protein of $\mathrm{HCV}$ co-localises with MxA in a granular pattern in the cytoplasm of cells, a phenomenon that is potentiated with the co-treatment of IFN- $\alpha$ and ribavirin [21]. Hepatic expression of MxA is a known predictor of response to IFN- $\alpha$ therapy $[22,23]$. Because of their role as key mediators of IFN- $\alpha$-induced antiviral activity, PKR, OAS and MxA were chosen as potential indicators of IFN$\alpha$ treatment responsiveness in this prospective study.

Prior to treatment, we measured in vitro responsiveness of PBMCs to IFN- $\alpha$ stimulation by quantifying PKR, OAS and MxA expression levels in IFN- $\alpha$ treated PBMCs isolated from HCV infected patients. We correlated ISG expression with the patient's subsequent clinical response to therapy and with other factors including IL28B genotype.

\section{Methods}

\section{Study population}

Patients $(n=41)$ from St. Vincent's University Hospital (SVUH) and St. James's Hospital Dublin (SJH), who were mono-infected with $\mathrm{HCV}$, were recruited. Written consent was obtained from each patient and ethical approval was obtained from the ethics and medical research committee at SVUH and the research ethics committee at $\mathrm{SJH}$, in accordance with the ethical guidelines of the 1975 Declaration of Helsinki. Patients were treated with pegylated IFN- $\alpha 2 \mathrm{a}$ or IFN- $\alpha 2 \mathrm{~b}$ in combination with ribavirin as previously described [24]. Patients who were HCV-RNA negative at week 4 of treatment were termed rapid virological responders (RVR); patients with a 2 log drop in viral RNA by week 12 were termed early virological responders (EVR); HCV-RNA -ve patients at the end of treatment were classed as having an end-oftreatment response (EOT); patients who were $\mathrm{HCV}$ RNA 6 months post treatment achieved SVR; and those who were HCV-RNA at EOT but had viral breakthrough 6 months post treatment were termed relapsers.

\section{PBMC preparation and stimulation}

Blood samples were collected in lithium heparin tubes and PBMCs were freshly isolated by density centrifugation using Ficoll-Paque separation medium (GE Healthcare, Sweden). $2 \times 10^{6}$ PBMCs per ml of RPMI, supplemented with $10 \%$ FCS and $250 \mathrm{U} / \mathrm{ml}$ penicillin, $250 \mu \mathrm{g} / \mathrm{ml}$ streptomycin, were cultured at $37^{\circ} \mathrm{C}$, and stimulated fresh with $100 \mathrm{IU}$ or 1000 IU pegylated IFN $\alpha-2 \mathrm{a}$ (Roche, Switzerland) for 2 and 4 hours. PBMCs were immediately lysed in Trizol reagent (Invitrogen, USA) following stimulation, thus preserving the RNA and stored at $-80^{\circ} \mathrm{C}$ until analysis.

\section{RNA Extraction and Quantitative Real-time PCR (qRT-PCR)}

RNA was extracted according to manufacturer's instructions and reverse transcribed using Omniscript (Invitrogen). qRT-PCR using SyBr green was performed on an

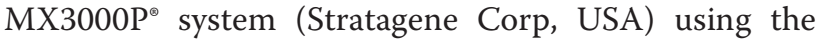


Table 1 Intron spanning primers for qRT-PCR analysis

\begin{tabular}{lcc}
\hline Gene & Sense & Antisense \\
\hline RPS15 & CGGACCAAAGCGATCTCTTC & CGCACTGTACAGCTGCATCA \\
MxA & GGTGGTGGTCCCCAGTAATG & ACCACGTCCACAACCTTGTCT \\
OAS & GAAGCCCTACGAAGAATGTCAGA & TCGGAGTTGCCTCTTAAGACTGT \\
PKR & TCTCAGCAGATACATCAGAGATAAATTCT & AGTATACTTTTTTCTTTCATGTCAGGAA \\
\hline
\end{tabular}

following cycling parameters: $95^{\circ} \mathrm{C}$ for $30 \mathrm{sec}, 60^{\circ} \mathrm{C}$ for $1 \mathrm{~min}$ and $72^{\circ} \mathrm{C}$ for $30 \mathrm{sec}$. Following geNORM analysis of a panel of housekeepers, the most stable housekeeping gene was found to be ribosomal protein 15 (RPS15) [25]. Gene amplifications were normalised to RPS15 and expressed on a log scale [26]. Primers are shown in Table 1.

\section{IL28B SNP analysis}

Rs12979860 genotype was determined from patient blood or serum samples using the LightMix Kit IL28B (Roche/Tib MolBiol).

\section{Statistical analysis}

Paired samples were analysed using Wilcoxon matchedpairs rank tests; for unpaired samples, non-parametric Mann-Whitney U tests and Fisher's exact test were used. Area under the curve (AUC) analysis was calculated from receiver operating characteristics (ROC) curve. $\mathrm{P}$ values $<0.05$ were considered statistically significant.

\section{Results}

Patient characteristics

Forty-one patients with chronic HCV infection were studied prospectively, the majority of whom had been infected via IV drug use (Table 2). Eighteen patietns were infected with genotype1 (G1) and 23 with genotype 3 (G3). Numbers of patients, gender ratios and ages were similar in both groups. Demographic, clinical, virological and genetic features were also similar. Liver enzyme levels (ALT p = 0.34 , AST $\mathrm{p}=0.5)$, viral load $(\mathrm{p}=0.31)$ and IL28B genotype $(\mathrm{CC} \mathrm{p}=0.5, \mathrm{CT} / \mathrm{TT} \mathrm{p}=0.36)$ were similar in both groups. Circulating lymphocytes tended to be lower in G1 infected patients $\left(1.8 \times 10^{3} / \mu \mathrm{l}\right)$ when compared with G3 infected patients $\left(2.3 \times 10^{3} / \mu \mathrm{l}\right)$ but this difference was not significant $(\mathrm{p}=0.06)$. Total white cell counts, neutrophil and monocyte counts were similar in both patient cohorts. Of the 41 patients recruited, 36 successfully completed therapy (G1 n=16, G3 n=20). Surprisingly, in this study there was no significant difference in response rates between G1 or G3 infected patients recruited (Table 3; RVR $42 \%$ vs $57 \%$ respectively, $\mathrm{p}=0.54 ;$ EVR $83 \%$ vs $90 \% \mathrm{p}=0.64$; EOT $72 \%$ vs $86 \% \mathrm{p}=0.68$; SVR $56 \%$ vs $65 \% \mathrm{p}=0.74)$.

\section{Pre-treatment ISG expression in PBMCs predicts SVR in} G1, but not G3, infected patients

To determine whether in vitro responsiveness of PBMCs to IFN- $\alpha$ could predict clinical response to therapeutic IFN- $\alpha$, PBMCs were isolated from patients before they commenced therapy, stimulated in vitro with IFN- $\alpha$ and ISG expression was quantified. G1 infected patients who successfully achieved SVR following treatment had significantly higher induction of PKR $(\mathrm{p}=0.0148)$, OAS ( $\mathrm{p}=$ $0.0019)$ and MxA ( $=0.0019$; Figure $1 B)$ following stimulation with IFN- $\alpha$ compared to G1 infected patients who failed to achieve SVR. As well as having higher induction of these ISGs following in vitro IFN- $\alpha$ stimulation, G1

Table 2 Clinical features

\begin{tabular}{|c|c|c|c|}
\hline Feature & Genotype 1 & Genotype 3 & P value* \\
\hline Patients (n) & 18 & 23 & $0.7^{\S}$ \\
\hline Males, n (\%) & $13(68)$ & $15(65)$ & $1^{\S}$ \\
\hline Females, n (\%) & $6(32)$ & $8(35)$ & \\
\hline Age (years -/+SD) & $44.6-/+13.2$ & $43.2-/+10.2$ & $0.19^{9}$ \\
\hline \multicolumn{4}{|l|}{ Risk factors, n (\%) } \\
\hline Injecting drug use & $7(39)$ & $12(52)$ & $0.53^{\S}$ \\
\hline Blood transfusion & $4(22)$ & $2(9)$ & $0.03^{\S}$ \\
\hline Anti-D immunoglobulin & $4(22)$ & $0(0)$ & $0.38^{\S}$ \\
\hline Not determined & $3(17)$ & $9(39)$ & $0.17^{\S}$ \\
\hline \multicolumn{4}{|l|}{ Liver enzyme levels } \\
\hline $\operatorname{ALT}(I U / L-/+S D)$ & $112.8-/+122.6$ & $107.4-/+86.3$ & $0.34^{q}$ \\
\hline AST (IU/L -/+SD) & $66.6-/+54.8$ & $69.2-/+59.5$ & $0.5^{\natural}$ \\
\hline \multicolumn{4}{|l|}{ Leukocyte counts } \\
\hline WCC $\left(\times 10^{9} / \mathrm{L}-/+\mathrm{SD}\right)$ & $5.7-/+2$ & $6.4-/+2.5$ & $0.3^{9}$ \\
\hline Neutrophils $\left(\times 10^{3} / \mu l\right)$ & $3.3-/+1.4$ & $3.4-/+1.7$ & $0.99^{9}$ \\
\hline Lymphocytes $\left(\times 10^{3} / \mu \mathrm{l}\right)$ & $1.8-/+0.6$ & $2.3-/+1$ & $0.06^{\mathbb{9}}$ \\
\hline Monocytes $\left(\times 10^{3} / \mu \mathrm{l}\right)$ & $0.46-/+0.13$ & $0.6-/+0.3$ & $0.17^{\natural}$ \\
\hline Viral load $\left.\left(\times 10^{6} \mathrm{IU} / \mathrm{ml}-/+\right) \mathrm{SD}\right)$ & $5.6-/+10.8$ & $7.5-/+1.3$ & $0.31^{9}$ \\
\hline \multicolumn{4}{|l|}{ IL-28B genotype n (\%) } \\
\hline $\mathrm{CC}$ & $4(22)$ & $8(35)$ & $0.5^{\S}$ \\
\hline $\mathrm{CT} / \mathrm{TT}$ & $10(56)$ & $9(39)$ & $0.36^{\S}$ \\
\hline Not determined & $4(22)$ & $6(26)$ & $1^{\S}$ \\
\hline
\end{tabular}

*Comparison between G1 and G3 infected patients.

${ }^{5}$ Fisher's exact test.

"Mann-Whitney $U$ test.

ALT alanine aminotrasferase, AST aspartate aminotransferase, WCC white cell count. 
Table 3 Clinical response to treatment

\begin{tabular}{lccc}
\hline Therapeutic outcome & Genotype $\mathbf{1}$ & Genotype 3 & P value $^{\text {\$ }}$ \\
\hline RVR (\%) & $8(42)$ & $13(57)$ & 0.54 \\
EVR (\%) & $15(83)$ & $20(90)$ & 0.64 \\
EOT (\%) & $13(72)$ & $19(86)$ & 0.68 \\
SVR (\%) & $10(62.5)$ & $13(65)$ & 0.74 \\
Relapse (\%) & $3(23)$ & $6(33)$ & 1 \\
\hline
\end{tabular}

${ }^{\S}$ Fisher's exact test.

infected patients who achieved SVR also had increased endogenous levels of PKR and MxA $(\mathrm{p}=0.0281$ and $\mathrm{p}=$ 0.0207 respectively; Figure 1A). Conversely, pre-treatment endogenous or IFN- $\alpha$ induced ISG expression was not consistently higher in G1 infected patients who achieved RVR (Additional file 1: Figure S1), EVR (Additional file 1: Figure S2) or EOT response (Additional file 1: Figure S3) compared to those who did not. Therefore, in G1 infected patients, enhanced ISG expression only correlated with SVR and not with other on-treatment response rates. In contrast to G1 infected patients, G3 infected patients showed no correlation with either endogenous ISG expression $(\mathrm{PKR} p=0.8107$, OAS $\mathrm{p}=0.3106, \mathrm{MxA} \mathrm{p}=0.5740$;
Figure $2 \mathrm{~A}$ ) or IFN- $\alpha$ stimulated ISG expression (PKR $\mathrm{p}=$ 0.9307 , OAS $\mathrm{p}=0.4833, \mathrm{MxA} \mathrm{p}=0.2103$; Figure $2 \mathrm{~B}$ ) and achieving an SVR.

To determine the predictive value of IFN- $\alpha$ responsiveness in G1 infected patients, ROC curves were calculated based on ISG expression following stimulation with IFN$\alpha$. PKR expression had an AUC of $0.86(p=0.016)$ while both OAS and MxA each had an AUC of 0.94 ( $\mathrm{p}=0.003)$ (Additional file 1: Table S1). We used predictive values of gene cut-off expression levels (generated from the AUC analysis) to evaluate which patients would respond to dual therapy and thus not require additional PIs. Of all three genes examined, MxA had the strongest predictive power, with a PPV of $100 \%$, a NPV of $88.9 \%$ and a likelihood ratio of 8 based on a cut-off of 91.2 , despite the low numbers of patients in the analysis.

Univariate analysis was used to determine whether other pre-treatment characteristics were predictive of treatment response in our G1 and G3 infected cohorts (Table 4). In G1 infected patients, PKR, OAS and MxA induction was the only significant predictor of SVR. Lack of response to therapy was not associated with altered numbers of white blood cells. In G3 infected

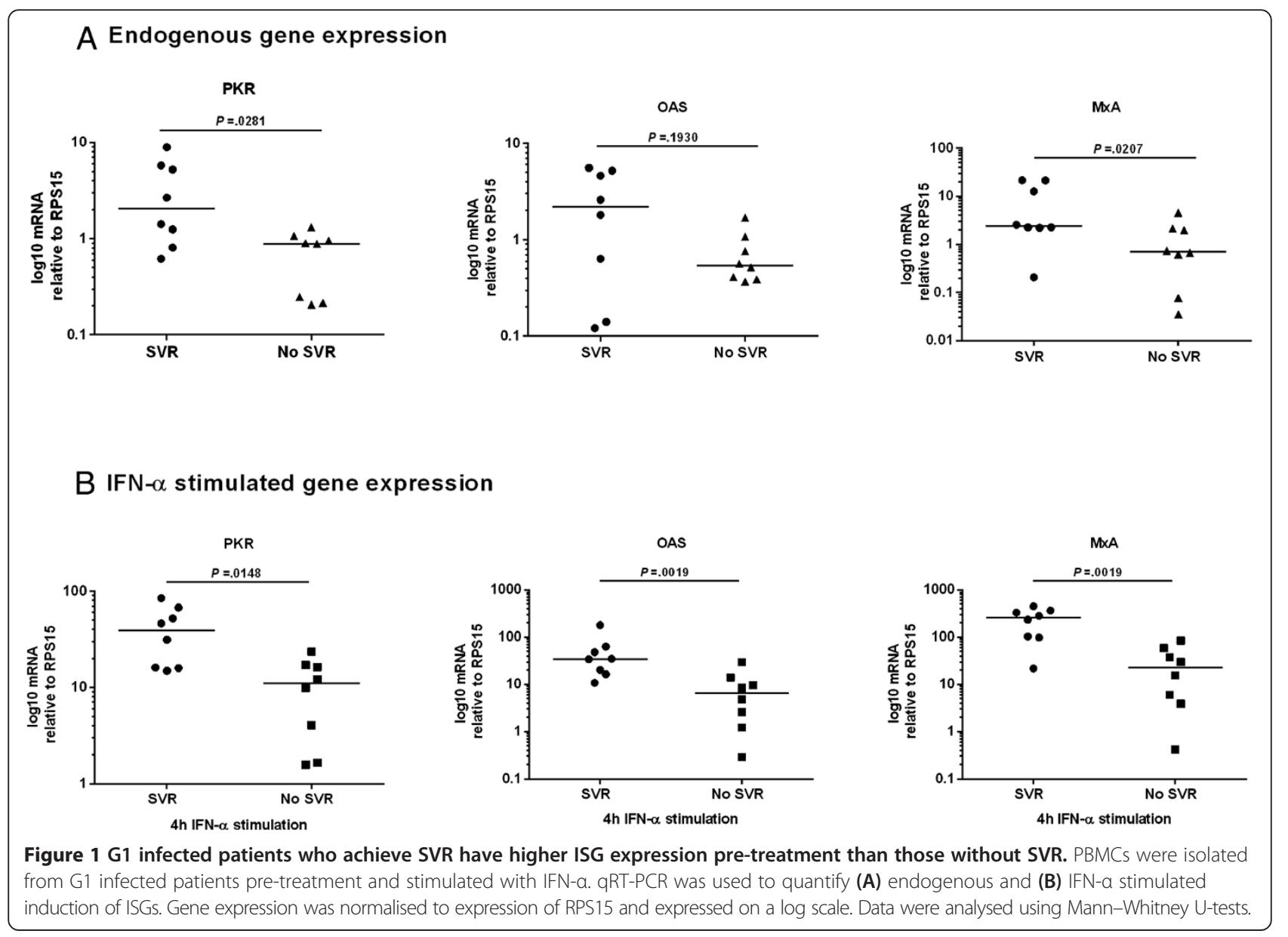




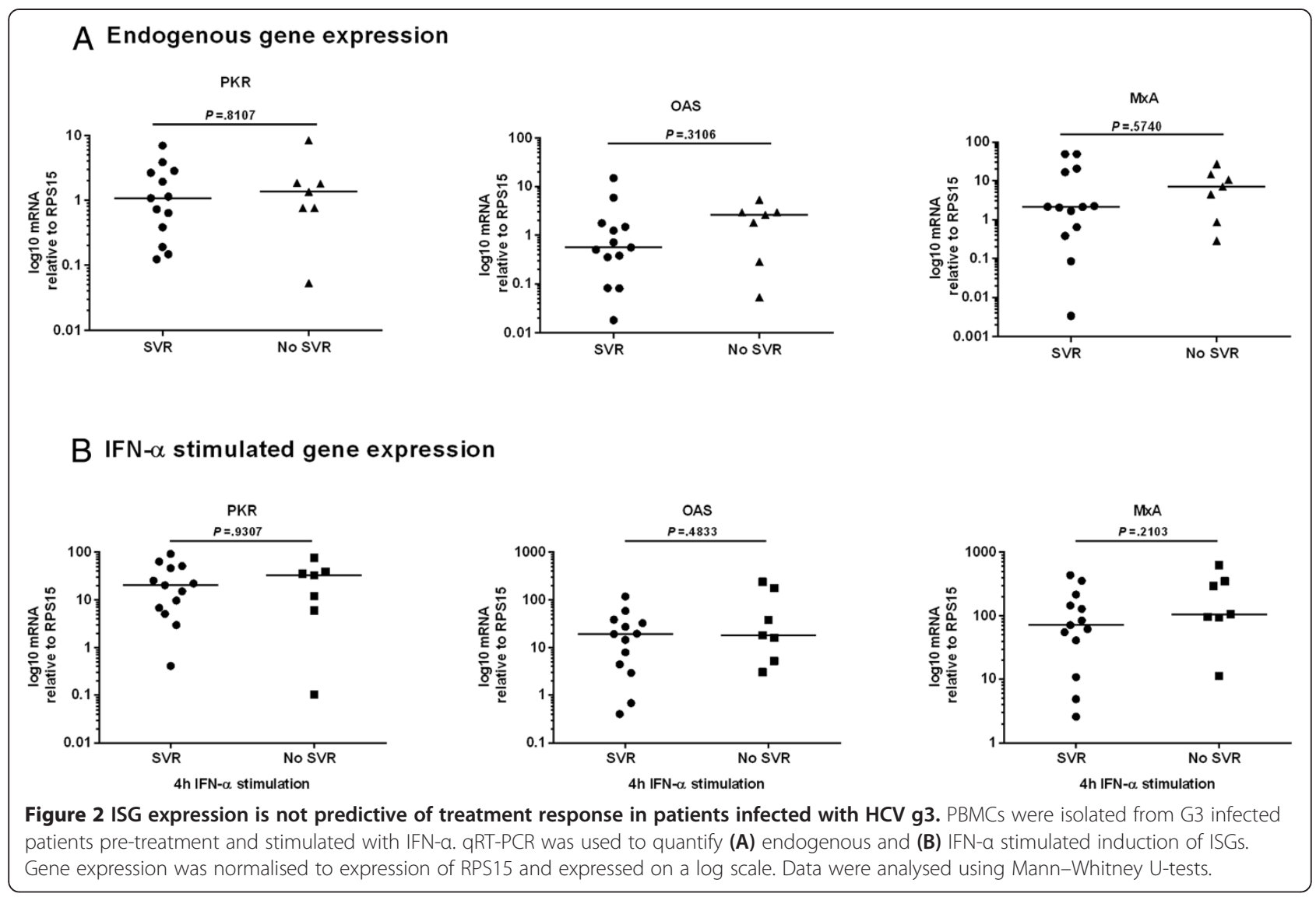

patients, achieving SVR was significantly associated with lower pre-treatment viral load $(\mathrm{p}=0.045)$ and younger age $(\mathrm{p}=0.03)$. Achieving RVR $(\mathrm{p}=0.06)$, and high pretreatment lymphocyte numbers $(\mathrm{p}=0.07)$ were also close to being significantly associated with SVR in this cohort.

\section{Rs12979860 genotype does not affect ISG expression in PBMCs from HCV infected patients}

In other studies, the SNP (rs12979860) in the IFN $\lambda 4$ gene, some distance from the IL28 genes, is highly predictive of treatment response [10,27]. ISG expression in liver tissue from $\mathrm{HCV}$ infected patients has been shown to correlate with rs12979860 genotype [12]. We therefore investigated whether rs12979860 genotype influenced ISG expression in PBMCs from HCV infected individuals in our study. IFN- $\alpha$ stimulation of PBMCs led to robust upregulation of ISG expression, regardless of whether patients carried the minor $\mathrm{T}$ allele for rs12979860 (Figure 3A), demonstrating that in vitro induction of IFN- $\alpha$ stimulated ISGs in PBMCs was independent of IL28B genotype. Additionally, rs12979860 genotype did not influence endogenous ISG levels in PBMCs. When ISG expression in patients who achieved SVR was compared to those who did not, and stratified based on rs12979860 genotype, there were no significant differences observed between patients with $\mathrm{CC}$ or $\mathrm{CT} /$ TT genotype (Figure $3 \mathrm{~B})$. There was also no difference in ISG expression and IL28B genotype between G1 and G3 infected patients (Figure 4).

\section{Discussion}

Approximately $50 \%$ of $\mathrm{HCV}$ infected patients infected with G1 achieve an SVR with IFN- $\alpha$ and ribavirin therapy and do not actually need additional PIs in their treatment regime. However, it has it has not hitherto been possible to identify responsive patients prior to commencing treatment. Here, we hypothesised that in vitro analysis of immune cell responsiveness to IFN- $\alpha$ stimulation prior to treatment would predict clinically responsive patients. In this prospective study, we found that G1 infected patients who achieved SVR could indeed be identified prior to treatment by the significantly greater ISG induction in their PBMCs following in vitro IFN- $\alpha$ stimulation than in PBMCs from G1 infected patients who did not achieve SVR. Interestingly, this finding seems to be exclusive to patients infected with GI as the clinical response of G3 infected patients could not be predicted pre-treatment. IL28B genotype did not influence ISG expression in PBMCs nor in vitro IFN- $\alpha$ stimulated responses and there was no difference in ISG expression between patients who 
Table 4 Univariate analysis of predictors of SVR in $\mathrm{g} 1$ and $\mathrm{g} 3$ infected patients

\begin{tabular}{|c|c|c|c|}
\hline Genotype 1 infected patients & SVR $(n=8)$ & No SVR $(n=8)$ & $P$ value \\
\hline Age (years -/+SD) & $40.9-/+4.2$ & $47.3-/+5.6$ & $0.4^{\pi}$ \\
\hline $\operatorname{Sex}(m / f)$ & $6 / 2$ & $4 / 4$ & $0.61^{\S}$ \\
\hline IL28B genotype (CC/CT or TT)* & $5 / 3$ & $5 / 1$ & $0.58^{\S}$ \\
\hline Fibrosis & $2.5-/+0.9$ & $1.7-/+0.6$ & $0.59^{\pi}$ \\
\hline $\operatorname{RVR}(\mathrm{Y} / \mathrm{N})$ & $4 / 4$ & $2 / 6$ & $0.61^{\S}$ \\
\hline Viral load $\left(\times 10^{6}\right)$ & $2.1-/+1.1$ & $5.6-/+3.1$ & $0.65^{\natural}$ \\
\hline \multicolumn{4}{|l|}{ Liver enzyme levels } \\
\hline ALT & $87-/+26.6$ & $44.1-/+8.6$ & $0.57^{\natural}$ \\
\hline AST & $162.3-/+58.2$ & $53.3-/+8.9$ & $0.19^{\natural}$ \\
\hline \multicolumn{4}{|l|}{ Leukocyte counts } \\
\hline White cell count & $5.6-/+1$ & $5.9-/+0.5$ & $0.56^{n}$ \\
\hline Neutrophils & $3.2-/+0.7$ & $3.3-/+0.4$ & $0.8^{\natural}$ \\
\hline Lymphocytes & $1.8-/+0.3$ & $1.9-/+0.2$ & $0.68^{n}$ \\
\hline Monocytes & $0.5-/+0.1$ & $0.4-/+0.05$ & $0.72^{\natural}$ \\
\hline \multicolumn{4}{|l|}{ ISG expression } \\
\hline PKR endogenous & $3.3-/+1.1$ & $0.7-/+0.1$ & $0.028^{\natural}$ \\
\hline OAS endogenous & $2.6-/+0.8$ & $0.7-1+0.2$ & $0.19^{\natural}$ \\
\hline MxA endogenous & $8.1-/+3.2$ & $1.3-/+0.5$ & $0.021^{\pi}$ \\
\hline PKR induction & $41.1-/+9.2$ & $10.8-/+2.8$ & $0.015^{\pi}$ \\
\hline OAS induction & $51-/+19.3$ & $8.8-/+3.4$ & $0.002^{n}$ \\
\hline MxA induction & $235-/+52.5$ & $29.7-/+10.6$ & $0.002^{q}$ \\
\hline Genotype 3 infected patients & SVR $(n=13)$ & No SVR $(n=7)$ & $P$ value \\
\hline Age (years -/+SD) & $39.6-/+1.9$ & $47-/+2.4$ & $0.03^{\pi}$ \\
\hline $\operatorname{Sex}(m / f)$ & $7 / 6$ & $5 / 2$ & $0.64^{\S}$ \\
\hline IL28B genotype (CC/CT or TT)* & $4 / 5$ & $4 / 3$ & $1^{\S}$ \\
\hline $\operatorname{RVR}(\mathrm{Y} / \mathrm{N})$ & $10 / 3$ & $2 / 5$ & $0.06^{\S}$ \\
\hline Viral load $\left(\times 10^{6}\right)$ & $7.8-/+3.8$ & $9.6-/+3.6$ & $0.045^{\natural}$ \\
\hline \multicolumn{4}{|l|}{ Liver enzyme levels } \\
\hline ALT & $93-/+17$ & $147-/+38$ & $0.24^{\pi}$ \\
\hline AST & $58.2-/+9.8$ & $109-/+25.6$ & $0.13^{n}$ \\
\hline \multicolumn{4}{|l|}{ Leukocyte counts } \\
\hline White cell count & $6.6-/+0.7$ & $5.8-/+0.8$ & $0.37^{\natural}$ \\
\hline Neutrophils & $3-1+0.5$ & $3.1-/+0.5$ & $0.76^{\pi}$ \\
\hline Lymphocytes & $2.7-/+0.3$ & $1.9-/+0.2$ & $0.07^{\natural}$ \\
\hline Monocytes & $0.6-/+0.1$ & $0.5-/+0.1$ & $0.71^{\natural}$ \\
\hline \multicolumn{4}{|l|}{ ISG expression } \\
\hline PKR endogenous & $2.1-/+0.5$ & $2-/+1$ & $0.81^{\natural}$ \\
\hline OAS endogenous & $2.2-/+1$ & $2-1+0.6$ & $0.31^{\natural}$ \\
\hline MxA endogenous & $11.4-/+4.4$ & $8.1-/+3.2$ & $0.57^{\natural}$ \\
\hline PKR induction & $29.1-/+6.9$ & $29.5-/+9.6$ & $0.93^{\natural}$ \\
\hline OAS induction & $23.9-/+8$ & $70.6-/+36.8$ & $0.48^{n}$ \\
\hline MxA induction & $126-/+34$ & $226.4-/+81.2$ & $0.21^{\natural}$ \\
\hline
\end{tabular}

$R V R$ rapid virological response, $A L T$ alanine aminotrasferase, $A S T$ aspartate aminotransferase.

"Data not available for all patients included in study.

${ }^{5}$ Fisher's exact test.

"Mann-Whitney $U$ test. 


\section{A ISG expression stratified based on rs12979860 genotype}
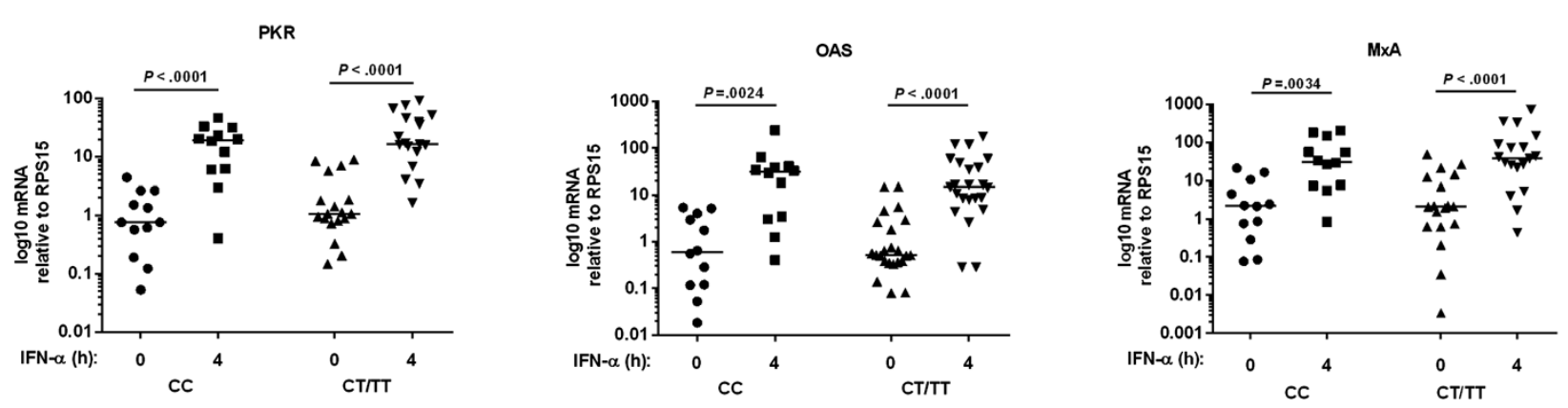

B ISG expression stratified based on rs12979860 genotype and treatment response
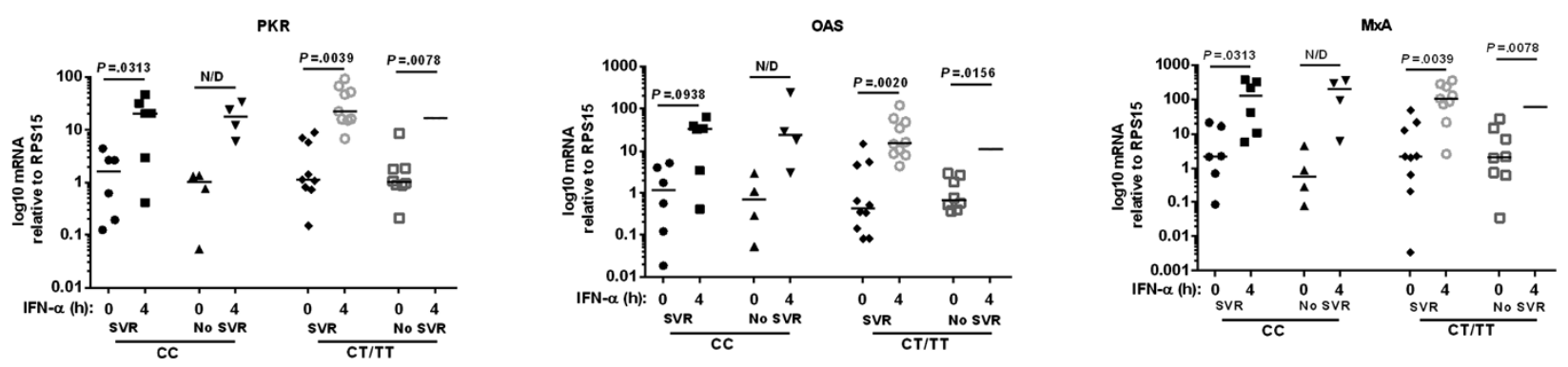

Figure 3 rs 12979860 genotype is independent of ISG expression in PBMCs from HCV infected patients. PBMCs were isolated from HCV infected patients pre-treatment and stimulated with IFN-a. QRT-PCR was used to quantify endogenous and IFN-a induced expression of ISGs. ISG expression was stratified based on (A) rs12979860 genotype and (B) rs12979860 genotype and treatment response. Gene expression was normalised to expression of RPS15 and expressed on a log scale. Each dot represents one sample and median gene expression is shown. Data were analysed using Wilcoxon matched-pairs rank test and Mann-Whitney U-tests; N/D = not determined due to low n number.

achieved SVR or did not achieve SVR among the different IL28B genotypes.

The development of DAAs is an exciting advance in treating $\mathrm{HCV}$ infection and offers many genotype 1 infected patients who would not respond to standard IFN- $\alpha$ therapy, additional options for treatment. However, currently licensed PIs are given in combination with dual IFN- $\alpha$ therapy, thus significantly increasing costs and introducing additional significant side effects. Trials involving DAAs in "IFN free" regimes are extremely promising for certain groups of patients, however IFN- $\alpha$ therapy still boasts a lack of drug-drug interactions, relatively low cost, lack of effect of viral resistant mutants and a long clinical track record [28]. Crucially, the cost of DAAs will prevent their large scale distribution in low and middle income countries, which have the highest rates of HCV infection, for the foreseeable future. Therefore, identification of subgroups of patients who would not require additional PIs would make significant economic savings.

Several predictors of response to dual therapy have previously been described including demographic, genetic and intrahepatic markers [3]. Studies have shown hepatic ISG expression to be a strong predictor of treatment response [11,29]. Using microarrays, others have shown that global transcriptional responses in PBMCs following in vivo and ex vivo IFN- $\alpha$ stimulation are different between responders and non-responders following treatment $[30,31]$. We found that G1 infected patients who achieved an SVR had significantly higher ISG expression in PBMCs prior to treatment. Pre-treatment, endogenous expression of PKR and MxA was lower in PBMCs from G1 infected patients who failed to achieve an SVR, contrasting with previous reports from the liver showing elevated pre-treatment ISG expression predictive of therapeutic non-responsive [11]. A range of IFN-sensitive mechanisms may already be activated in $\mathrm{HCV}$-infected liver, which harbours mixed populations of cells including epithelial and endothelial cells as well as hepatocytes and immune cells. In comparison, PBMCs provide a more accessible homogenous population for use as a resource for identifying patients who are responsive to IFN- $\alpha$.

Interestingly, pre-treatment ISG expression in PBMCs from G3 infected patients could not predict SVR, yet ISG expression was strongly predictive of therapeutic response in G1 infected patients, suggesting that HCV G1 may differ significantly from G3 in its ability to target IFN- $\alpha$ 


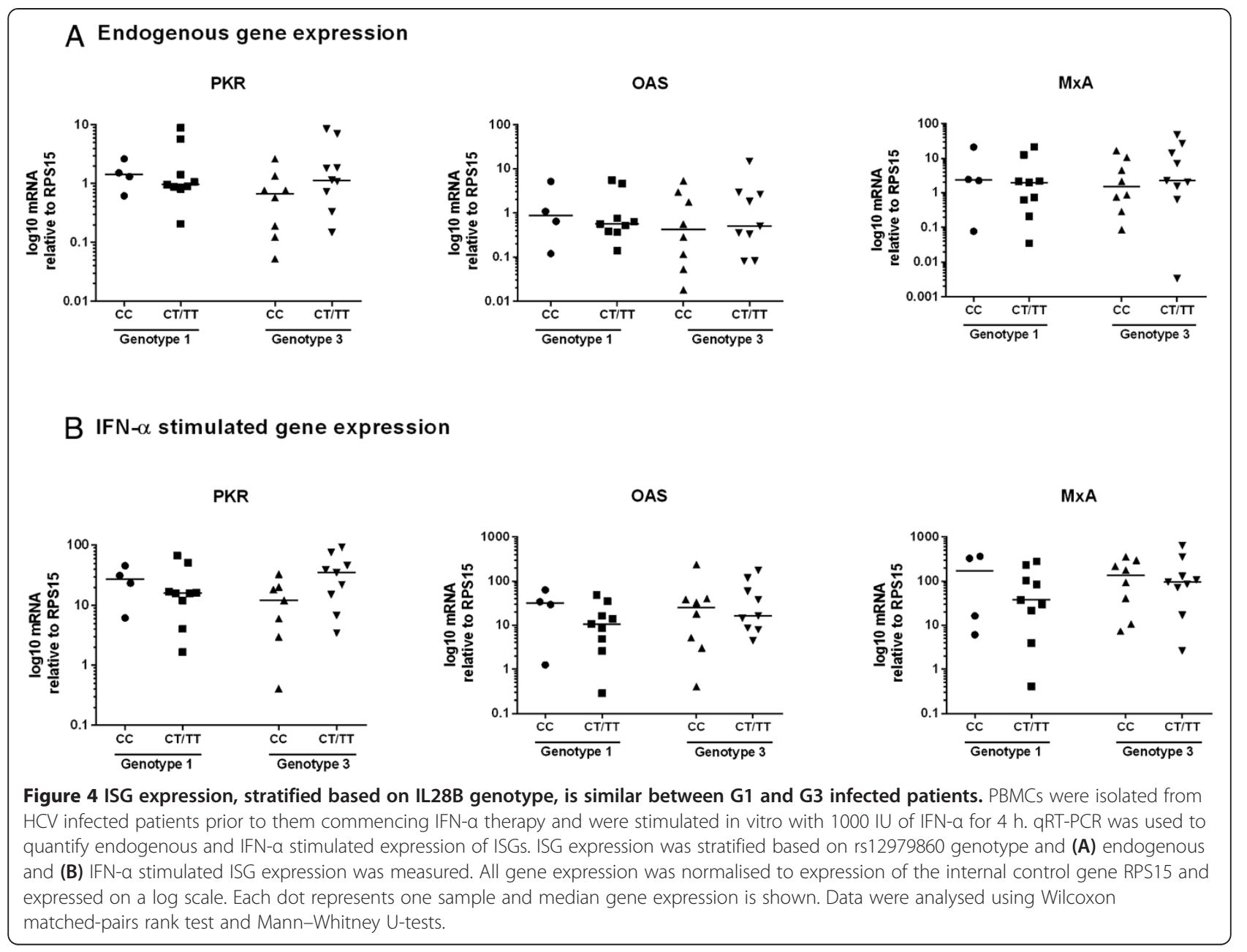

signalling. Several HCV proteins, including the NS3-4A protease, are known inhibitors of the IFN response $[32,33]$. We recently found that HCV G1 degrades signal transducers and activator of transcription 1 (STAT1) and STAT3, key transcription factors activated by IFN- $\alpha$ signalling, and showed that this suppression was consistent across all PBMC subsets [34]. However, it is possible that $\mathrm{HCV}$ genotypes differentially target IFN- $\alpha$ signalling perhaps explaining the differences in ISG expression we observed in G1 and G3 infected patients.

Patients who have rapid decreases in viral load and achieve an RVR have a 90\% chance of achieving overall SVR [35]. However, we found that pre-treatment ISG expression was not strongly associated with RVR, suggesting that ISG expression in PBMCs is independent of RVR, in accordance with a study by Sarasin-Filipowicz et al. [29]. That study did not examine SVR. Unusually, RVR was not predictive of overall SVR in our G1 infected cohort. Although ISG expression tended to be higher in patients who achieved EVR or were PCR -ve at the end of treatment compared to RVR in G1 infected patients, the strongest association seen was that between pre-treatment ISG expression and SVR.

In this study, we analysed expression of three welldefined anti-viral genes (PKR, OAS and MxA) that have been shown using microarray analysis to be upregulated in PBMCs and specific immune cell subsets, including macrophages, DCs and NK cells, following in vitro IFN- $\alpha$ stimulation [2,36-39]. IFN- $\alpha$ is a strong regulator of gene expression in PBMCs and Zimmerer et al. demonstrated that in vitro stimulation of PBMCs mimics in vivo effects [40]. This study also demonstrated that T cells, monocytes and NK cells all respond to in vitro IFN- $\alpha$ stimulation. Recently, a retrospective analysis of G1 infected $\mathrm{HCV}$ patients of mixed race demonstrated that SVR and monocyte activation in response to $24 \mathrm{~h}$ in vitro stimulation with IFN- $\alpha$ were negatively correlated but failed to show any correlation between IFN- $\alpha$ induced myeloid and plasmacytoid dendritic cell activation and therapeutic response. In our study, we found enhanced responses to $4 \mathrm{~h}$ in vitro stimulation in unseparated PBMCs from G1 infected 
patients was associated with SVR, indicating that duration of IFN- $\alpha$ stimulation is critical.

The rs12979860 SNP, located upstream of the IL28B gene and present in the novel IFN $\lambda 4$ gene [8], is a robust predictor of spontaneous viral clearance and response to treatment in some cohorts $[9,10]$. Of note, hepatic ISG expression has also been shown to be a stronger predictor of response than IL28B genotype [12,22]. The predictive value of IL28B is increased when combined with the predictive power of other known indicators of response, such as serum CXCL10 levels [41]. Amongst our G1 infected patients, ISG expression in PBMCs was more predictive of therapeutic response than IL28B genotype which was a surprising result given the strong predictive power of this SNP in other studies [10,27]. However, it is possible that the IL28B genotype is not a strong predictor in all cohorts; indeed MxA staining in hepatic macrophages has been found to be a better predictor of SVR than IL28B genotype in a Canadian cohort [22]. Endogenous ISG expression has been shown to be higher in livers from patients carrying the minor $\mathrm{T}$ allele for rs12979860 [12], yet we found that in PBMCs, ISG expression was similar between patients of any genotype. Microarray studies have shown that ISG expression in PBMCs from G1 infected patients was independent of IL28B genotype [42]. In a HCV/HIV coinfected cohort of patients, induction of ISGs following 12 hours of in vivo stimulation with IFN- $\alpha$, was independent of IL28B genotype, echoing our findings in PBMCs from $\mathrm{HCV}$ infected patients.

\section{Conclusions}

In vitro responsiveness of PBMCs from G1 infected patients to IFN- $\alpha$ stimulation pre-treatment identifies patients who will achieve SVR on dual therapy. These patients do not need additional PIs to clear the virus. Reliable identification of patients who do not require triple therapy would provide significant cost benefits, reduce side effects and halt the emergence of PI resistant strains of virus.

\section{Additional file}

Additional file 1: Figure S1. Correlation between RVR and ISG expression. PBMCs were stimulated in vitro with $100 \mathrm{IU}$ or $1000 \mathrm{IU}$ of IFN-a for 2 or $4 \mathrm{~h}$. qRT-PCR was used to quantify ISG expression. Analysis stratified into those who achieved RVR and those who did not. (A) all viral genotypes, (B) g1 infected patients and (C) g3 infected patients. All gene expression was normalised to expression of RPS15 and expressed on a log scale. Mann-Whitney statistical analysis, ${ }^{*} p<0.05$. Figure S2. Correlation between EVR and ISG expression. PBMCs were stimulated in vitro with $100 \mathrm{IU}$ or $1000 \mathrm{IU}$ of IFN-a for 2 or $4 \mathrm{~h}$. qRT-PCR was used to quantify ISG expression. Analysis stratified into those who achieved EVR and those who did not. (A) all viral genotypes (B) g1 infected patients and (C) g3 infected patients. All gene expression was normalised to expression of RPS15 and expressed on a log scale. Mann-Whitney statistical analysis, ${ }^{*} p<0.05$. Figure S3. Correlation between EOT response and ISG expression. PBMCs were stimulated in vitro with $100 \mathrm{IU}$ or $1000 \mathrm{IU}$ of IFN-a for 2 or $4 \mathrm{~h}$. qRT-
PCR was used to quantify ISG expression. Analysis stratified into those who were $P C R$-ve at EOT and those who were PCR +ve. (A) all viral genotypes, (B) g1 infected patients and (C) g3 infected patients. All gene expression was normalised to expression of RPS15 and expressed on a log scale. Mann-Whitney statistical analysis, ${ }^{*} p<0.05$, ${ }^{* *} p<0.01$. Table S1. Predictability of SVR based on cut-off gene expression values. Gene cut-off values quantified following $4 \mathrm{~h}$ in vitro IFN-a stimulation, as determined by qRT-PCR, were analysed to predict response of $\mathrm{g} 1$ infected patients to respond to therapeutic IFN-a using receiver operating characteristic (ROC) analysis. AUC: area under curve in ROC analysis, $\mathrm{Cl}$ : confidence intervals, PPV: positive predictive value, NPV: negative predictive value.

\section{Abbreviations}

IFN-a: Interferon-alpha; HCV: Hepatitis C virus; PBMCs: Peripheral blood mononuclear cells; ISGs: Interferon stimulated genes; SVR: Sustained virological response; G1: Genotype 1; G3: Genotype 3; RVR: Rapid virological response; EVR: Early virological response; EOT: End of treatment; DAAs: Direct acting antivirals; Pl: Protease inhibitor; AUC: Area under the curve; PPV: Positive predictive value; NPV: Negative predictive value.

\section{Competing interests}

The authors declare that they have no competing interests.

\section{Authors' contributions}

NMB, NJS and COF designed the experiments and wrote the manuscript. NB and SS performed experiments. NB, MTON, SS, NJS and COF discussed and interpreted the data. MTON, SS, SN and JH provided clinical insight, discussed and interpreted the data and reviewed the manuscript. COF directed the study. All authors read and approved the final manuscript.

\section{Acknowledgements}

This work was supported by Science Foundation Ireland (08/RFP/BMT1403) and the Irish Health Research Board (TRA/2007/14). We thank all patient volunteers, Carol McNulty and all the nurses who assisted in sample collection. We also thank Catherine Keogh and Aideen Collins for technical assistance.

\section{Author details}

${ }^{1}$ School of Biochemistry and Immunology, Trinity Biomedical Sciences Institute, Trinity College Dublin, Dublin 2, Ireland. ${ }^{2}$ Liver Centre, Mater Misericordiae University Hospital, Dublin 7, Ireland. 'Liver Unit, St. Vincent's University Hospital, Dublin 4, Ireland. ${ }^{4}$ Hepatology Unit, St. James's Hospital, Dublin 8, Ireland. ${ }^{5}$ School of Medicine, Trinity College, Dublin 2, Ireland.

Received: 3 April 2014 Accepted: 10 June 2014

Published: 21 July 2014

\section{References}

1. De Veer MJ, Holko M, Frevel M, Walker E, Der S, Paranjape JM, Silverman RH, Williams BR: Functional classification of interferon-stimulated genes identified using microarrays. J Leukoc Biol 2001, 69:912-920.

2. Sadler AJ, Williams BRG: Interferon-inducible antiviral effectors. Nat Rev Immunol 2008, 8:559-568.

3. Liver EAftSot: EASL Clinical Practice Guidelines: management of hepatitis C virus infection. J Hepatol 2011, 55:245-264.

4. Jacobson IM, McHutchison JG, Dusheiko G, Di Bisceglie AM, Reddy KR, Bzowej NH, Marcellin P, Muir AJ, Ferenci P, Flisiak R, George J, Rizzetto M, Shouval D, Sola R, Terg RA, Yoshida EM, Adda N, Bengtsson L, Sankoh AJ, Kieffer TL, George S, Kauffman RS, Zeuzem S, Advance Study Team: Telaprevir for previously untreated chronic hepatitis $C$ virus infection. N Engl J Med 2011, 364:2405-2416.

5. Poordad F, McCone J, Bacon BR, Bruno S, Manns MP, Sulkowski MS, Jacobson IM, Reddy KR, Goodman ZD, Boparai N, Dinubile MJ, Sniukiene V, Brass CA, Albrecht JK, Bronowicki JP, HCV Resond-2 investigators: Boceprevir for untreated chronic HCV genotype 1 infection. N Engl J Med 2011, 364:1195-1206.

6. Asselah T, Estrabaud E, Bieche I, Lapalus M, De Muynck S, Vidaud M, Saadoun D, Soumelis V, Marcellin P: Hepatitis C: viral and host factors associated with non-response to pegylated interferon plus ribavirin. Liver Int 2010, 30:1259-1269. 
7. Lagging M, Romero Al, Westin J, Norkrans G, Dhillon AP, Pawlotsky JM, Zeuzem S, Von Wagner M, Negro F, Schalm SW, Haagmans BL, Ferrari C, Missale G, Neuman AU, Verheij-Hart E, Hellstrand K, DITTO-HCV study group: IP-10 predicts viral response and therapeutic outcome in difficult-to-treat patients with HCV genotype 1 infection. Hepatology 2006, 44:1617-1625.

8. Prokunina-Olsson L, Muchmore B, Tang W, Pfeiffer RM, Park H, Dickensheets H, Hergott D, Porter-Gill P, Mumy A, Kohaar I, Chen S, Brand N, Tarway M, Liu L, Sheikh F, Astemborski J, Bonovsky HL, Edlin BR, Howell CD, Morgan TR, Thomas DL, Rehermann B, Donnelly RP, O'Brien TR: A variant upstream of IFNL3 (IL28B) creating a new interferon gene IFNL4 is associated with impaired clearance of hepatitis C virus. Nat Genet 2013, 41:579-584.

9. Tanaka Y, Nishida N, Sugiyama M, Kurosaki M, Matsuura K, Sakamoto N, Nakagawa M, Korenaga M, Hino K, Hige S, Ito Y, Mita E, Tanaka E, Mochida S, Murawaki Y, Honda M, Sakai A, Hiasa Y, Nishiguchi S, Koike A, Sakaida I, Imamura M, Ito K, Yano K, Masaki N, Sugauchi F, Izumi N, Tokunaga K, Mizokami M: Genome-wide association of IL28B with response to pegylated interferon-[alpha] and ribavirin therapy for chronic hepatitis C. Nat Genet 2009, 41:1105-1109.

10. Ge D, Fellay J, Thompson AJ, Simon JS, Shianna KV, Urban TJ, Heinzen EL, Qiu P, Bertelsen AH, Muir AJ, Sulkowski M, McHutchinson JG, Goldstein DB: Genetic variation in IL28B predicts hepatitis C treatment-induced viral clearance. Nature 2009, 461:399-401.

11. Chen L, Borozan I, Feld J, Sun J, Tannis LL, Coltescu C, Heathcote J, Edwards AM, McGilvray ID: Hepatic gene expression discriminates responders and nonresponders in treatment of chronic hepatitis $C$ viral infection. Gastroenterology 2005, 128:1437-1444

12. Dill MT, Duong FH, Vogt JE, Bibert S, Bochud PY, Terracciano L, Papassotiropoulos A, Roth V, Heim MH: Interferon-Induced Gene Expression Is a Stronger Predictor of Treatment Response Than IL28B Genotype in Patients With Hepatitis C. Gastroenterology 2010, 140:1021-1031.

13. Ji X, Cheung R, Cooper S, Li Q, Greenberg HB, He XS: Interferon alfa regulated gene expression in patients initiating interferon treatment for chronic hepatitis C. Hepatology 2003, 37:610-621.

14. Der SD, Zhou A, Williams BR, Silverman RH: Identification of genes differentially regulated by interferon alpha, beta, or gamma using oligonucleotide arrays. Proc Natl Acad Sci U S A 1998, 95:15623-15628.

15. Balachandran S, Roberts PC, Brown LE, Truong H, Pattnaik AK, Archer DR, Barber GN: Essential role for the dsRNA-dependent protein kinase PKR in innate immunity to viral infection. Immunity 2000, 13:129-141.

16. Gale MJ Jr, Korth MJ, Tang NM, Tan S-L, Hopkins DA, Dever TE, Polyak SJ, Gretch DR, Katze MG: Evidence That Hepatitis C Virus Resistance to Interferon Is Mediated through Repression of the PKR Protein Kinase by the Nonstructural 5A Protein. Virology 1997, 230:217-227.

17. Taylor DR, Shi ST, Romano PR, Barber GN, Lai MM: Inhibition of the interferon-inducible protein kinase PKR by HCV E2 protein. Science 1999, 285:107-110.

18. Chakrabarti A, Jha BK, Silverman $\mathrm{RH}$ : New insights into the role of RNase $\mathrm{L}$ in innate immunity. J Interferon Cytokine Res 2011, 31:49-57.

19. Malathi K, Saito T, Crochet N, Barton DJ, Gale M, Silverman RH: RNase L releases a small RNA from HCV RNA that refolds into a potent PAMP. RNA 2010, 16:2108-2119.

20. Haller $O$, Staeheli $P$, Kochs G: Interferon-induced Mx proteins in antiviral host defense. Biochimie 2007, 89:812-818

21. Stevenson NJ, Murphy AG, Bourke NM, Keogh CA, Hegarty JE, O'Farrelly C: Ribavirin Enhances IFN-a Signalling and MxA Expression: A Novel Immune Modulation Mechanism during Treatment of HCV. PLOS ONE 2011, 6:e27866.

22. McGilvray I, Feld JJ, Chen L, Pattullo V, Guindi M, Fischer S, Borozan I, Xie G, Selzner N, Heathcote EJ, Siminovitch K: Hepatic cell-type specific gene expression better predicts HCV treatment outcome than IL28B genotype. Gastroenterology 2012, 142:1122-1131.e1121.

23. Cheng JC, Yeh YJ, Huang YH, Liang KH, Chang ML, Lin CY, Yeh CT: Hepatic expression of MxA and OAS1 in an ex vivo liver slice assay independently predicts treatment outcomes in chronic hepatitis C. J Viral Hepat 2012, 19:e154-e162.

24. Sarwar S, Ryan EJ, labal M, McCormick PA, O'Farrelly C, Hegarty J: Rapid, early and sustained virological responses in a cohort of Irish patients treated with pegylated interferon and ribavirin for chronic hepatitis $C$ virus infection. Ir J Med Sci 2011, 181:53-58.
25. Vandesompele J, De Preter K, Pattyn F, Poppe B, Van Roy N, De Paepe A, Speleman F: Accurate normalization of real-time quantitative RT-PCR data by geometric averaging of multiple internal control genes. Genome Biol 2002, 3:RESEARCH0034.

26. Livak KJ, Schmittgen TD: Analysis of relative gene expression data using real-time quantitative PCR and the 2(-Delta Delta $C(T))$ Method. Methods 2001, 25:402-408.

27. Suppiah V, Moldovan M, Ahlenstiel G, Berg T, Weltman M, Abate ML, Bassendine M, Spengler U, Dore GJ, Powell E, Riordan S, Sheridan D, Smedile A, Frogomeli V, Muller T, Bahlo M, Stewart GJ, Booth DR, George J: IL28B is associated with response to chronic hepatitis C interferon-[alpha] and ribavirin therapy. Nat Genet 2009, 41:1100-1104.

28. Manns MP, Von Hahn T: Novel therapies for hepatitis C - one pill fits all? Nat Rev Drug Discov 2013, 12:595-610

29. Sarasin-Filipowicz M, Oakeley EJ, Duong FH, Christen V, Terracciano L, Filipowicz W, Heim MH: Interferon signaling and treatment outcome in chronic hepatitis C. Proc Natl Acad Sci U S A 2008, 105:7034-7039.

30. Taylor MW, Tsukahara T, Brodsky L, Schaley J, Sanda C, Stephens MJ, McClintick JN, Edenberg HJ, Li L, Tavis JE, Howell C, Belle SH: Changes in gene expression during pegylated interferon and ribavirin therapy of chronic hepatitis $C$ virus distinguish responders from nonresponders to antiviral therapy. J Virol 2007, 81:3391-3401.

31. He XS, Ji X, Hale MB, Cheung R, Ahmed A, Guo Y, Nolan GP, Pfeffer LM, Wright TL, Risch N, Tibshirani R, Greenberg HB: Global transcriptional response to interferon is a determinant of $\mathrm{HCV}$ treatment outcome and is modified by race. Hepatology 2006, 44:352-359.

32. Foy E, Li K, Wang C, Sumpter R, Ikeda M, Lemon SM, Gale M: Regulation of interferon regulatory factor- 3 by the hepatitis $C$ virus serine protease. Science 2003, 300:1145-1148.

33. Blindenbacher A, Duong FH, Hunziker L, Stutvoet ST, Wang X, Terracciano L, Moradpour D, Blum HE, Alonzi T, Tripodi M, La Monica N, Heim MH: Expression of hepatitis $\mathrm{c}$ virus proteins inhibits interferon alpha signaling in the liver of transgenic mice. Gastroenterology 2003, 124:1465-1475.

34. Stevenson NJ, Bourke NM, Ryan EJ, Binder M, Fanning L, Johnston JA, Hegarty JE, Long A, O'Farrelly C: Hepatitis C Virus targets the Interferon-a JAK/STAT pathway by promoting proteasomal degradation in immune cells and hepatocytes. FEBS Lett 2013, 10:1571-1578.

35. Yu JW, Wang GQ, Sun LJ, Li XG, Li SC: Predictive value of rapid virological response and early virological response on sustained virological response in HCV patients treated with pegylated interferon alpha-2a and ribavirin. J Gastroenterol Hepatol 2007, 22:832-836

36. Taylor MW, Grosse WM, Schaley JE, Sanda C, Wu X, Chien SC, Smith F, Wu TG, Stephens M, Ferris MW, McClintick JN, Jerome RE, Edenberg HJ: Global effect of PEG-IFN-alpha and ribavirin on gene expression in PBMC in vitro. J Interferon Cytokine Res 2004, 24:107-118.

37. Stegmann KA, Björkström NK, Veber $H$, Ciesek $S$, Riese $P$, Wiegand J, Hadem J, Suneetha PV, Jaroszewicz J, Wang C, Schlaphoff V, Fytili P, Cornberg M, Manns MP, Geffers R, Pietschmann T, Guzman CA, Ljunggren $H G$, Wedemeyer H: Interferon-alpha-induced TRAIL on natural killer cells is associated with control of hepatitis C virus infection. Gastroenterology 2010, 138:1885-1897.

38. Tassiulas I, Hu X, Ho H, Kashyap Y, Paik P, Hu Y, Lowell CA, Ivashkiv LB: Amplification of IFN-alpha-induced STAT1 activation and inflammatory function by Syk and ITAM-containing adaptors. Nat Immunol 2004, 5:1181-1189.

39. Dhodapkar KM, Banerjee D, Connolly J, Kukreja A, Matayeva E, Veri MC, Ravetch JV, Steinman RM, Dhodapkar MV: Selective blockade of the inhibitory Fcgamma receptor (FcgammaRIIB) in human dendritic cells and monocytes induces a type I interferon response program. J Exp Med 2007, 204:1359-1369.

40. Zimmerer JM, Lesinski GB, Ruppert AS, Radmacher MD, Noble C, Kendra K, Walker MJ, Carson WE: Gene expression profiling reveals similarities between the in vitro and in vivo responses of immune effector cells to IFN-alpha. Clin Cancer Res 2008, 14:5900-5906.

41. Beinhardt S, Aberle JH, Strasser M, Dulic-Lakovic E, Maieron A, Kreil A, Rutter K, Staettermayer AF, Datz C, Scherzer TM, Strassl R, Bischof M, Strauber R, Bodlaj G, Laferi H, Holzmann H, Steindl-Munda P, Ferenci P, Hofer H: Serum level of IP-10 increases predictive value of IL28B polymorphisms for spontaneous clearance of acute HCV infection. Gastroenterology 2012, 142:78-85.e72. 
42. Naggie S, Osinusi A, Katsounas A, Lempicki R, Herrmann E, Thompson AJ, Clark PJ, Patel K, Muir AJ, McHutchison JG, Schlaak JF, Trippler M, Schiakumar B, Masur H, Polis MA, Kottilil S: Dysregulation of innate immunity in hepatitis C virus genotype 1 IL28B-unfavorable genotype patients: impaired viral kinetics and therapeutic response. Hepatology 2012, 56:444-454.

doi:10.1186/1479-5876-12-206

Cite this article as: Bourke et al: In vitro blood cell responsiveness to IFN-a predicts clinical response independently of IL28B in hepatitis C virus genotype 1 infected patients. Journal of Translational Medicine 2014 12:206

\section{Submit your next manuscript to BioMed Central and take full advantage of:}

- Convenient online submission

- Thorough peer review

- No space constraints or color figure charges

- Immediate publication on acceptance

- Inclusion in PubMed, CAS, Scopus and Google Scholar

- Research which is freely available for redistribution 